\title{
PENGARUH MOTIVASI DAN PERSEPSI TENTANG PEMBELAJARAN MATA DIKLAT KOMPETENSI KEJURUAN APK TERHADAP HASIL BELAJAR SISWA DI SMK NEGERI 1 PAMEKASAN
}

\author{
Ruri Nurul Aeni Wulandari, Pascasarjana UNESA \\ rurinurul13@gmail.com
}

\begin{abstract}
ABSTRAK
Penelitian ini bertujuan untuk menganalisis pengaruh motivasi dan persepsi tentang pembelajaran mata diklat kompetensi kejuruan APK terhadap hasil belajar siswa di SMK Negeri 1 Pamekasan. populasi penelitian ini adalah kelas XI tahun ajaran 2014-2015 dengan total 119 siswa. Pengambilan sampel mengunakan teknik simple random sampling sebanyak 92 siswa. Teknik pengumpulan data menggunakan kuesioner dan dokumentasi. Penelitian ini merupakan penelitian kuantitatif dengan analisis regresi linear berganda. Hasil menunjukkan bahwa baik secara parsial maupun simultan, motivasi dan persepsi berpengaruh signifikan terhadap hasil belajar siswa di SMK Negeri 1 Pamekasan. Pengaruh yang paling besar dalam penelitian yaitu variabel persepsi pada hasil belajar siswa SMK Negeri 1 Pamekasan sebesar 37\%.
\end{abstract}

Kata Kunci: motivasi belajar, persepsi, dan hasil belajar siswa

\begin{abstract}
The purpose of this research was to analyze the influence of motivation and perceptions about vocational competency lessons on student learning results in SMKN 1 Pamekasan. The population consists of 119 students of class XI SMKN 1 Pamekasan academic year 2013-2014. 92 students as sample are taken by simple random sampling. Technique of data collection using questionnaires and documentation. This research used the quantitative approach and data were be analyzed using multiple linear regression. The results show that the partially and simultaneously motivation and perceptions have a significant effect on student learning results in SMKN 1 Pamekasan. greatest Influence is perceptions on student learning by $37 \%$.
\end{abstract}

Keywords: motivation, perceptions, and student learning results

\section{PENDAHULUAN}

Pendidikan merupakan usaha sadar dan terencana untuk mewujudkan suasana belajar dan proses pembelajaran agar peserta didik secara aktif mengembangkan potensi dirinya untuk memiliki kekuatan spiritual keagamaan, pengendalian diri, kepribadian, kecerdasan, akhlak mulia, serta keterampilan yang diperlukan dirinya dan masyarakat sehingga kualitas dirinya dapat ditingkatkan. Sebagaimana yang ditulis dalam UU Republik Indonesia No 20 tahun 2003 tentang sistem pendidikan nasional yang menyatakan bahwa sistem pendidikan nasional harus mampu menjamin pemerataan kesempatan pendidikan, peningkatan mutu serta relevansi dan efisiensi manajemen pendidikan untuk menghadapi tantangan sesuai dengan tuntutan perubahan kehidupan lokal, 
nasional, dan global sehingga perlu dilakukan pembaharuan pendidikan secara terencana, terarah, dan berkesinambungan. Hal tersebut sejalan dengan yang diungkapkan oleh Arikunto (2008) yang menyatakan bahwa setiap negara tentu mempunyai cita-cita serta harapan yang terbaik untuk warga negaranya ke mana mereka akan diarahkan. Cita-cita dan harapan tersebut dimanifestasikan dalam bentuk tujuan pendidikan.

Sekolah menengah kejuruan (SMK) merupakan pendidikan kejuruan tingkat menengah atas yang disediakan pemerintah dalam rangka menyiapkan tenaga kerja siap pakai. Hal ini sesuai dengan tujuan instruksional pendidikan menengah kejuruan yang terdapat dalam UU Republik Indonesia No 20 tahun 2003 ayat Pasal 26 ayat 3 yaitu pendidikan yang diharapkan mampu menjadikan siswa menjadi tenaga profesional yang memiliki keterampilan yang memadai, produktif, kreatif dan mampu berwirausaha. Berbagai upaya untuk mencapai tujuan pendidikan tersebut telah dilakukan oleh pemerintah antara lain dengan jalan, melengkapi sarana dan prasarana, meningkatkan kualitas tenaga pengajar, serta penyempurnaan kurikulum yang menekankan pada pengembangan aspek-aspek yang bermuara pada peningkatan dan pengembangan kecakapan hidup (Life Skill) yang diwujudkan melalui pencapaian kompetensi peserta didik untuk dapat menyesuaikan diri, dan berhasil di masa yang akan datang.

Hal yang biasanya dijadikan ukuran keberhasilan belajar siswa biasanya merupakan hasil belajar siswa di sekolah. Seperti yang diungkapkan oleh Sudjana (2011) hasil belajar digunakan untuk mengetahui sejauh mana tindakan atau kegiatan belajar mengajar dapat mencapai tujuan-tujuan instruksional yang dicapai dan dikuasai oleh siswa. Berdasarkan hasil observasi yang telah dilakukan sebelumnya pada bulan Maret sampai Mei, diketahui bahwa hasil belajar siswa jurusan administrasi perkantoran di SMK Negeri 1 Pamekasan pada mata diklat produktif jurusan APK kurang mengalami peningkatan yang signifikan. Dengan nilai rata-rata 70-75 per-semester dari tahun ajaran 2013-2014 yang harus dicapai oleh para siswa rata-rata para siswa dapat memenuhi standar ketuntasan minimal dengan melakukan beberapa kali remedial di setiap mata diklat yang diajarkan. Hal tersebut akhirnya membuat peneliti kemudian tertarik untuk mengadakan observasi lebih lanjut mengapa hasil belajar siswa SMK Negeri 1 Pamekasan tersebut dapat terjadi.

Dalam proses pembelajaran yang dilakukan oleh siswa SMK selain untuk peningkatan keterampilan, kemampuan pemahaman dan penguasaan materi juga menjadi acuan dan tolak ukur keberhasilan dalam kegiatan pembelajaran. Karena bentuk kemampuan memahami dan menguasai materi pembelajaran secara teori maupun aplikasi sangat diperlukan bagi siswa SMK, maka penanganan dalam proses belajar mengajar pun harus lebih intensif lagi sehingga nantinya siswa SMK dapat mampu menguasai suatu pelajaran yang didapatkan di sekolah itu secara utuh jadi tidak hanya teori atau tidak hanya praktik saja, akan tetapi mereka memiliki kedua kemampuan tersebut untuk keterampilan mereka dimasa-masa yang akan datang. Untuk itu perlu kiranya siswa SMK dibekali dengan kemampuan dasar dan keterampilan teknik yang memadai.

Salah satu upaya yang dapat membantu pengembangan proses belajarmengajar agar bisa tercapai secara optimal menurut Wayan (2008) adalah dengan mengenali serta meneliti berbagai faktor yang mempengaruhi siswa dalam proses belajar mengajar. Hal ini nantinya diharapkan dapat menjadi referensi bagi guru 
untuk meningkatkan hasil belajar sehingga siswa memiliki prestasi yang baik. Karena menurut Sulistiana, dkk (2013) prestasi belajar yang dimiliki oleh siswa tidak hanya dipengaruhi oleh faktor internal akan tetapi juga melalui faktor eksternal yang ada.

Salah satu faktor yang peneliti anggap berpengaruh terhadap hasil belajar siswa yaitu motivasi. Hal ini sesuai dengan yang diungkapkan oleh Uno (2007) dalam proses pembelajaran motivasi memiliki peranan penting untuk memperoleh hasil belajar yang baik, karena apabila seorang siswa yang telah termotivasi untuk belajar sesuatu, maka dia akan berusaha mempelajarinya dengan baik dan tekun, dengan harapan memperoleh hasil yang memuaskan. Demikian pula seperti yang diungkapkan oleh Hamdu, dkk (2011) bahwa motivasi merupakan salah satu hal yang berpengaruh pada kesuksesan aktifitas pembelajaran siswa, karena tanpa motivasi, proses pembelajaran akan sulit mencapai kesuksesan yang optimal.

Sesuai dengan hasil observasi dan wawancara terdahulu yang dilakukan oleh peneliti pada bulan Februari-Maret 2013. Peneliti menemukan beberapa kasus menyangkut motivasi belajar siswa APK di SMK Negeri 1 Pamekasan pada mata diklat produktif kompetensi kejuruan kelas XI khususnya pada mata diklat sarana dan prasarana. Hal ini dapat dilihat dari masih terdapat siswa yang pasif pada saaat mata diklat tersebut. Seperti misalnya: siswa suka datang terlambat, ada yang mengerjakan pekerjaan rumah (PR) di sekolah, ada yang suka ke kantin pada waktu proses belajar mengajar sedang berlangsung, dan adanya handphone dengan berbagai macam aplikasi yang menyita perhatian siswa, sehingga mengakibatkan siswa sibuk bermain pada saat jam pelajaran sehingga secara perlahan namun pasti hal- hal tersebut dapat mengikis motivasi belajar siswa di sekolah.

Karena satu hal yang pasti menurut Uno (2007) motivasi dapat menjelaskan mengapa ada orang berperilaku tertentu untuk mencapai serangkaian tujuan yang diinginkannya. Hal ini sejalan dengan yang diungkapkan oleh Bruno dalam Syah (2005) yang menjelaskan bahwa sikap (attitude) adalah kecendrungan yang relatif menetap untuk bereaksi dengan cara baik atau buruk terhadap orang atau barang. Dengan demikian pada prinsipnya sikap itu dapat dianggap sebagai kecendrungan siswa untuk bertindak dengan cara tertentu. Sehingga apabila siswa tidak memiliki persepsi maupun motivasi yang baik maka dari keterangan diatas akan terdapat perbedaan dari hasil belajar mereka.

Faktor lainnya yang peneliti anggap sebagai faktor yang memiliki peran penting dalam meningkatkan hasil belajar siswa adalah persepsi dari siswa itu sendiri, sejalan dengan yang disampaikan oleh Slameto (2010) bahwa persepsi yang dimiliki itu bersifat selektif, dan seseorang memiliki kecendrungan hanya memperhatikan beberapa rangsangan saja dari banyaknya rangsangan yang ada di sekelilingnya. Sehingga dapat disimpulkan bahwa siswa akan menerima suatu pelajaran dengan baik tergantung pada apa yang ia pernah pelajari, apa yang pada saat itu menarik perhatiannya dan ke arah mana persepsi yang dimilikinya mempunyai kecendrungan.

Dalam observasi dan wawancara yang juga telah dilakukan sebelumnya, baik itu kepada guru maupun kepada siswa kelas XI jurusan APK di SMK Negeri 1 Pamekasan, peneliti mengambil kesimpulan sementara bahwa persepsi siswa pada pelajaran mata diklat produktif khususnya pada mata diklat sarana dan prasarana masih kurang. Hal ini dikarenakan menurut siswa mereka kurang 
memahami apa yang disampaikan oleh guru pada saat pelajaran karena kurangnya sumber belajar yang mumpuni, hal ini juga mengakibatkan hasil belajar tidak dapat optimal. Padahal menurut Warsita (2008) dalam pembelajaran yang ada di sekolah, perlu mengembangkan keseluruhan kecerdasan yang dimiliki siswa, untuk menjamin siswa menjadi juara, oleh karena itu dalam aplikasinya perlu adanya sumber belajar yang memadai.

Hal lain yang dikeluhkan oleh siswa dan juga guru di SMK Negeri 1 Pamekasan adalah kurang tersedianya media pembelajaran yang mendukung proses belajar mengajar pada mata diklat sarana dan prasarana. Padahal dalam pendidikan, pemakaian media menurut Syukur, dkk (2008) sangat berkaitan dengan perkembangan psikologi belajar siswa. Hal tersebut mengakibatkan peran media dalam pendidikaan saat ini sangatlah penting. Hal tersebut yang kemudian mendorong penulis untuk melakukan penelitian dengan judul "Pengaruh Motivasi dan Peresepsi Siswa Tentang Pembelajaran Mata Diklat Kompetensi Kejuruan APK Terhadap Hasil Belajar Di SMK Negeri 1 Pamekasan."

Suyono dan Hariyanto (2011) menyatakan bahwa belajar adalah suatu aktivitas ataupun suatu proses untuk memperoleh pengetahuan, meningkatkan keterampilan, memperbaiki perilaku, sikap, dan mengokohkan kepribadian. Begitupun yang dikemukakan oleh Ahmadi (2007) bahwa belajar adalah proses perubahan di dalam diri manusia, sesuai dengan tujuan yang telah ditetapkan sebelumnya. Sehingga dapat disimpulkan bahwa belajar adalah proses perubahan tingkah laku karena adanya pengalaman yang dimiliki seseorang secara sengaja dilakukan untuk memperoleh hasil yang diharapkan.

Sedangkan hasil belajar seperti yang disampaikan oleh Sudjana (2011) pada hakikatnya merupakan perubahan tingkah laku sebagai hasil belajar dalam pengertian yang lebih luas mencakup bidang kognitif, afektif, dan psikomotorik. Lalu Dimyati dan Mudjiono (2006) juga menjelaskan bahwa hasil belajar merupakan hasil dari suatu interaksi tindak belajar dan tindak mengajar. Sebagai salah satu indikator pencapaian dari tujuan pembelajaran yang berlangsung di kelas, hasil belajar tidak terlepas dari faktor-faktor yang mempengaruhi hasil belajar itu sendiri. menurut Sugihartono (2007), yaitu faktor dari dalam diri peserta didik (intern) antara lain jasmani (kondisi kesehatan maupun cacat tubuh) dan faktor psikologis (intelegensi, perhatian, minat, bakat, motif, kematangan maupun kesiapan). Sedangkan faktor lainnya yaitu faktor yang ada di luar individu (extern) antara lain, keluarga, sekolah dan masyarakat.

Akan tetapi menurut Djamarah dan Aswan (2002) hasil belajar seringkali diartikan sebagai hasil akhir pengambilan keputusan tentang tinggi dan rendahnya nilai peserta didik selama mengikuti proses pembelajaran, sehingga pembelajaran dikatakan berhasil apabila tingkat pengetahuan siswa bertambah dari sebelumnya. Demikian halnya juga seperti yang disampaikan oleh Tu'u (2004) bahwa hasil belajar lazimnya ditunjukkan dengan nilai tes angka ataupun nilai yang diberikan guru, kemudian tertuang dalam bentuk skor yang diperoleh siswa di sekolah. Skor yang diperoleh tersebut biasanya dimasukkan ke dalam bentuk laporan yang disebut nilai ulangan harian ataupun rapor.

Selanjutnya untuk motivasi, Uno (2007) secara jelas menyatakan bahwa motivasi belajar merupakan dorongan internal dan eksternal pada siswa-siswa yang sedang belajar untuk mengadakan perubahan tingkah laku, pada umumnya dengan mengacu pada beberapa indikator yang mendukung. Pernyataan tersebut 
didukung oleh Hasibuan (2001) yang menyatakan bahwa Motivasi berasal dari kata latin "movere" yang berarti dorongan atau menggerakkan. Dan juga yang diungkapkan oleh Hamalik (2001) bahwa motivasi merupakan perubahan energi dalam diri (pribadi) seseorang yang ditandai dengan timbulnya perasaan dan reaksi untuk mencapai tujuan.

Sedangkan klasifikasi indikator dari motivasi belajar sendiri masih menurut Uno (2007) antara lain adanya hasrat dan keinginan berhasil, adanya dorongan dan kebutuhan dalam belajar, adanya harapan dan cita-cita masa depan, adanya penghargaan dalam belajar, adanya kegiatan yang menarik dalam belajar dan yang terakhir adalah adanya lingkungan belajar yang kondusif sehingga memungkinkan siswa nantinya dapat belajar dengan baik.

Selanjutnya untuk persepsi menurut Sarlito (2009) yang menyatakan bahwa persepsi merupakan hasil dari sejumlah penginderaan yang disatukan dan dikoordinasikan dalam pusat saraf yang lebih tinggi (otak) sehingga manusia dapat mengenal dan menilai objek yang ada maupun lingkungan sekitar. Sehingga dapat disimpulkan bahwa persepsi merupakan tanggapan yang dilakukan oleh seseorang setelah mendapatkan rangsangan maupun stimulus dari lingkungan sekitar. Hal tersebut didukung oleh pernyataan dari Slameto (2010) Persepsi adalah proses yang menyangkut masuknya pesan atau informasi ke dalam otak manusia. Karena melalui persepsi, manusia terus-menerus mengadakan hubungan dengan lingkungannya. Hubungan ini dilakukan lewat inderanya, yaitu indera penglihatan, pendengar, peraba, perasa dan pencium. Dan juga yang disampaikan oleh Sugihartono (2007) bahwa persepsi adalah kemampuan otak dalam menerjemahkan stimulus atau proses untuk menerjemahkan/mengintrepetasi stimulus yang masuk kedalam alat indera.

Dari pendapat diatas kemudian Alfan (2013) mengambil kesimpulan bahwa persepsi dapat dilihat dari seseorang yang mengalami proses persepsi ditunjukkan oleh perilakunya dan menggunakan kecakapan inderawinya untuk menyadari adanya rangsangan yang ada. Selanjutnya persepsi tersebut dapat menimbulkan tanggapan atau penerimaan siswa yaitu tanggapan langsung dalam menafsirkan apa yang ditangkap oleh panca indera oleh siswa. Proses terjadinya persepsi itu sendiri menurut Walgito (2003) antara lain dapat dilihat dari proses kealaman, proses fisiologis, dan yang terakhir adalah proses psikologis. Dalam penelitian ini persepsi dlihat dari dua sub indikator yaitu dilihat dari media pembelajaran dan sumber belajar.

Proses pembelajaran di Sekolah Menengah Kejuruan (SMK) pada hakikatnya bertujuan untuk menghasilkan lulusan yang siap kerja, hal ini sesuai dengan tujuan institusional yang diharapkan dapat dicapai oleh SMK. Dalam konteks pembelajaran di SMK tersebut khususnya pada mata diklat kompetensi kejuruan diperlukan banyak kreatifitas dan inovasi dari guru untuk meningkatkan hasil belajar. Hal lainnya yang memiliki peran penting dalam meningkatkan hasil belajar siswa antara lain adalah motivasi dan persepsi siswa seperti yang telah dijelaskan sebelumnya, hal ini sesuai dengan penelitian terdahulu antara lain yang dilakukan oleh Steep dan Greany (2002) yang mengungkapkan bahwa dengan adanya perubahan teknologi pembelajaran mengakibatkan persepsi siswa lebih kearah yang positif. Serta yang diungkapkan oleh Luis, dkk (2007) yang melakukan penelitian dengan menggunakan 1000 siswa sebagai objek penelitian, 
selanjutnya peneliti mengambil kesimpulan bahwa persepsi siswa memiliki pengaruh yang signifikan terhadap prestasi mereka.

Sedangkan untuk variabel motivasi antara lain adalah penelitian yang dilakukan oleh Aritonang (2008) yang menunjukkan bahwa terdapat hubungan yang signifikan antara variabel motivasi belajar terhadap hasil belajar yang diperoleh. Begitu pula yang diungkapkan oleh Wayan (2008) bahwa motivasi menunjukkan hubungan yang korelasional dengan hasil belajar siswa, hal tersebut kemudian memberi petunjuk bahwa jika ingin meramalkan hasil belajar, maka motvasi juga merupakan salah satu faktor pentingnya.

\section{METODE PENELITIAN}

Pendekatan penelitian yang digunakan dalam penelitian ini adalah penelitian kuantitatif. Sedangkan jenis penelitian yang digunakan adalah penelitian tingkat eksplanasi (level of explanation). Berdasarkan tingkat eksplanasi, penelitian ini termasuk penelitian asosiatif. Variabel yang digunakan dalam penelitian ini adalah motivasi belajar $\left(\mathrm{X}_{1}\right)$ dan persepsi $\left(\mathrm{X}_{2}\right)$ pada hasil belajar $(\mathrm{Y})$ siswa kelas XI APK di SMKN 1 Pamekasan.

Populasi dalam penelitian ini adalah siswa kelas XI APK SMK Negeri 1 Pamekasan sebanyak 119 siswa. Jumlah sampel yang digunakan sebanyak 92 siswa. Sampel ditentukan dengan menggunakan rumus Slovin. Teknik pengambilan sample yang digunakan adalah Teknik probability sampling dengan jenis simple random sampling. Menurut Sugiyono (2011) Simple random sampling yaitu cara pengambilan sampel dari anggota populasi dengan menggunakan acak tanpa memperhatikan strata atau tingkatan dalam anggota populasi tersebut. Hal ini dilakukan apabila populasi dianggap sejenis (homogen).

Data dikumpulkan menggunakan kuesioner dan dokumentasi. Dokumentasi digunakan untuk mengumpulkan data dari variabel hasil belajar siswa dengan menggunakan hasil nilai ulangan mata diklat kompetensi kompetensi kejuruan sarana dan prasarana APK semester ganjil kelas XI tahun 2014/2015. Sedangkan kuesioner digunakan untuk mengumpulkan data dari variabel motivasi belajar dan persepsi siswa. Kuesioner disusun berdasarkan variabel penelitian dan indikator penelitian dengan skala pengukuran instrument menggunakan skala likert.

Teknik analisis menggunakan analisis regresi linear berganda dengan kriteria uji $\mathrm{F}$ dan uji t. Uji $\mathrm{F}$ digunakan untuk menguji signifikansi variabel gender, motivasi, dan persepsi tentang pembelajaran mata diklat kompetensi kejuruan APK terhadap hasil belajar siswa Di Smk Negeri 1 Pamekasan secara simultan. Sedangkan uji t digunakan untuk menguji signifikansi motivasi dan persepsi pada hasil belajar siswa secara parsial.

\section{HASIL DAN PEMBAHASAN}

Model regresi yang diperoleh berdasarkan hasil penelitian, dapat dituliskan dalam betuk persamaan regresi sebagai berikut $Y=\mathbf{- 3 3 , 6 4 1}+\mathbf{0 ,}, \mathbf{8 8 5} \mathrm{X}_{\mathbf{1}}+\mathbf{0 , 7 1 8}$ $\mathbf{X}_{2}+\mathbf{e}_{\mathbf{i}}$. Dari persamaan regresi tersebut, variabel bebas dukungan motivasi belajar memiliki koefisien regresi dengan arah positif. Hal ini berarti semakin baik motivasi belajar akan meningkatkan hasil belajar siswa. Begitu pula dengan variabel bebas dukungan persepsi memiliki koefisien regresi dengan arah positif. 
Hal ini berarti semakin baik persepsi yang dimiliki siswa akan meningkatkan hasil belajar siswa. Selanjutnya hasil uji F berdasarkan ANOVA atau uji statistik F, menunjukkan bahwa Fhitung yaitu 61,546 dengan tingkat signifikan kurang dari $5 \%$ yaitu 0,000 . Hal ini menunjukkan bahwa motivasi dan persepsi siswa tentang pembelajaran mata diklat kompetensi kejuruan APK secara bersama-sama memiliki pengaruh terhadap hasil belajar siswa kelas XI APK di SMKN 1 Pamekasan.

Besarnya koefisien korelasi adalah 0,58 menunjukkan bahwa hasil belajar siswa dipengaruhi oleh motivasi dan persepsi siswa sebesar 58\% sedangkan $42 \%$ dipengaruhi oleh faktor-faktor lain selain variabel dalam penelitian ini.

Uji t digunakan untuk mengetahui pengaruh motivasi dan persepsi secara parsial pada hasil belajar siswa. Uji parsial menunjukkan variabel motivasi belajar $\left(\mathrm{X}_{1}\right)$ sebesar 5.727 dengan tingkat signifikan kurang dari pada 5\% yaitu 0.000 . Artinya motivasi belajar $\left(\mathrm{X}_{1}\right)$ secara parsial berpengaruh signifikan pada hasil belajar siswa $(\mathrm{Y})$. persepsi siswa $\left(\mathrm{X}_{2}\right)$ sebesar 7.231 dengan tingkat signifikan kurang dari $5 \%$ yaitu 0.000 . Artinya persepsi siswa $\left(\mathrm{X}_{2}\right)$ secara parsial berpengaruh signifikan pada hasil belajar siswa (Y).

Berdasarkan hasil analisis menunjukkan bahwa motivasi siswa berpengaruh signifikan dan positif pada hasil belajar siswa kelas XI APK. Hasil tersebut mempunyai makna bahwa motivasi siswa akan meningkat apabila hasil belajar siswa kelas XI APK ditingkatkan. Semakin tinggi motivasi siswa, semakin baik pula hasil belajar siswa kelas XI APK di SMK Negeri 1 Pamekasan.

Hasil penelitian ini mendukung teori-teori yang telah diungkapkan antara lain oleh, Dalyono (2010) yang mengungkapkan bahwa motivasi dapat menentukan baik tidaknya dalam mencapai tujuan sehingga semakin besar motivasinya akan semakin besar kesuksesan belajarnya. Hal yang sama juga diungkapkan oleh Uno (2007) yang menyatakan bahwa dalam proses pembelajaran motivasi memiliki peranan penting untuk memperoleh hasil belajar yang baik, karena apabila seorang siswa yang telah termotivasi untuk belajar sesuatu, maka dia akan berusaha mempelajarinya dengan baik dan tekun, dengan harapan memperoleh hasil yang memuaskan. Dan juga menurut Djamarah dan Aswan (2002) mengemukakan bahwa dalam proses belajar, motivasi belajar sangat diperlukan sebab seseorang yang tidak mempunyai motivasi dalam belajar tidak akan mungkin melakukan aktivitas belajar. Sehingga dengan aktivitas belajar maka akan mempengaruhi hasil belajar.

Hasil penelitian ini juga mendukung berbagai hasil penelitian sebelumnya, hasil penelitian terdahulu tersebut antara lain yang dilakukan oleh, Aritonang (2008) yang menyatakan bahwa hasil belajar dipengaruhi oleh motivasi belajar siswa, dan faktor yang paling utama menentukan apakah siswa akan berminat dan termotivasi untuk belajar adalah faktor guru. Selain itu, Kiswoyowati (2011) yang menyatakan bahwa motivasi belajar memiliki pengaruh yang positif dan signifikan. Selain itu hasil penelitian yang juga mendukung adalah dari Wiyono (2008), Hamdu (2011), dan Rahman (2011) yang menyatakan bahwa motivasi belajar berpengaruh signifikan dan positif terhadap hasil belajar siswa. Penelitian terdahulu yang dilakukan di luar negeri juga mendukung hasil penelitian ini yaitu penelitian yang dilakukan oleh Lee (2010) dan Sarwar (2012) yang hasilnya terdapat pengaruh yang signifikan antara motivasi belajar terhadap prestasi belajar. 
Motivasi siswa berpengaruh signifikan pada hasil belajar siswa kelas XI APK di SMK Negeri 1 Pamekasan didukung oleh temuan pada variabel motivasi siswa dalam penelitian ini lebih dominan didukung oleh indikator "hasrat keinginan berhasil". Hal ini dapat ditunjukkan dari temuan bahwa sebagian siswa di SMK Negeri 1 Pamekasan memiliki cita-cita yang ingin mereka wujudkan, hal ini mendorong keinginan mereka untuk memiliki hasil belajar yang tinggi.

Akan tetapi pada temuan selanjutnya, walaupun sebagian siswa memiliki hasrat keinginan berhasil yang tinggi sehingga meningkatkan motivasi diri mereka untuk memperoleh hasil yang baik, indikator "lingkungan belajar yang kondusif sehingga memungkinkan siswa nantinya dapat belajar dengan baik" masih kurang, hal ini dapat dilihat dari temuan yang menunjukkan bahwa dalam proses belajar mengajar khususnya pada mata diklat sarana dan prasarana di SMK Negeri 1 Pamekasan lingkungan belajar siswa kurang mendukung proses belajar berjalan secara kondusif, hal ini dapat dilihat dari kelas yang kurang terawat, sehingga memungkinkan siswa tidak berkonsentrasi dikarenakan adanya gangguan dari luar, baik itu teman yang mengajak untuk membolos pada saat jam mata diklat berlangsung, maupun orang-orang yang berlalulalang di sekitar kelas.

Hasil dari temuan yang ada diatas menunjukkan bahwa kurangnya siswa berkonsentrasi dapat disebabkan proses pembelajaran yang dilakukan masih pasif sehingga permasalahan dari siswa adalah siswa memiliki motivasi yang tinggi namun pada proses belajar berlangsung siswa merasa kurang percaya diri untuk menyampaikan pertanyaan kepada guru, menjawab pertanyaan dari guru dan menyampaikan pendapatnya. Dengan ini guru dapat memberikan solusi permasalahan siswa dengan memancing siswa untuk aktif dalam bertanya yaitu diawali dengan memberikan materi dengan sebuah contoh permasalahan yang menarik, kemudian memberikan sebuah pertanyaan kepada siswa sehingga siswa tertarik untuk menyampaikan pendapatnya. Dengan adanya proses pembelajaran yang menarik maka akan dapat membantu siswa untuk aktif dalam proses pembelajaran.

Berdasarkan uraian tersebut dapat disimpulkan bahwa siswa SMK Negeri 1 Pamekasan memiliki motivasi belajar yang tinggi. Dengan demikian maka guru mata diklat kompetensi kejuruan khususnya pada mata diklat sarana dan prasarana dalam memberikan materi pelajaran dapat memberikan motivasi kepada siswa untuk aktif dalam pembelajaran berlangsung agar motivasi belajar siswa tetap tinggi dan hasil belajar siswa tidak menurun.

Berdasarkan hasil analisis menunjukkan bahwa persepsi siswa tentang pembelajaran mata diklat kompetensi kejuruan APK khususnya mata diklat sarana dan prasarana berpengaruh signifikan dan positif pada hasil belajar siswa kelas XI APK. Hasil tersebut mempunyai makna bahwa persepsi siswa tentang pembelajaran mata diklat kompetensi kejuruan APK akan meningkat apabila hasil belajar siswa kelas XI APK ditingkatkan. Semakin baik persepsi siswa terhadap mata diklat sarana dan prasarana, semakin baik pula hasil belajar siswa kelas XI APK di SMK Negeri 1 Pamekasan.

Hasil penelitian ini kemudian mendukung teori sebelumnya, diantaranya dikemukakan oleh Alfan (2013) bahwa persepsi siswa merupakan tanggapan atau penerimaan siswa yang berupa tanggapan langsung dalam menafsirkan apa yang ditangkap oleh panca indera siswa. Dan juga yang diungkapkan oleh Slameto (2010) yang mengungkapkan bahwa persepsi adalah proses yang menyangkut 
masuknya pesan atau informasi ke dalam otak manusia. Karena melalui persepsi, manusia terus-menerus mengadakan hubungan dengan lingkungannya. Hubungan ini dilakukan lewat inderanya, yaitu indera penglihatan, pendengar, peraba, perasa dan pencium. Dilihat dari hal tersebut dapat diungkapkan bahwa adanya persepsi siswa tentang pembelajaran mata diklat kompetensi kejuruan apk yang baik maka diharapkan bahwa nantinya hasil belajar dari siswa tersebut juga akan meningkat.

Selain teori yang telah disebutkan diatas, penelitian ini juga sejalan dengan penelitian sebelumnya, yang dilakukan oleh Rosilawati (2011) menunjukkan bahwa persepsi siswa memiliki hubungan yang positif terhadap hasil belajar yang dilakukan di sekolah. Hal yang serupa diungkapkan oleh Stepp dan Greany (2002) yang menunjukkan bahwa adanya perubahan teknologi pembelajaran mengakibatkan persepsi siswa semakin bertambah positif.

Persepsi siswa berpengaruh signifikan terhadap hasil belajar siswa SMK Negeri 1 Pamekasan khususnya pada mata diklat sarana dan prasarana didukung oleh temuan pada indikator yang lebih dominan yaitu "pemanfaatan media elektronik atau alat sebagai sumber belajar". Hal ini dapat ditunjukkan dari temuan bahwa sebagian siswa mendapatkan informasi tentang mata diklat sarana dan prasarana yang dipelajari lebih banyak dari intensitas penggunaan media internet sebagai sumber belajar mereka yang ditunjang dengan tersedianya laboratorium computer yang cukup untuk praktek siswa kelas XI APK di SMK Negeri 1 Pamekasan dibanding dengan penggunaan media ataupun sumber belajar lainnya.

Temuan selanjutnya pada variabel persepsi siswa yaitu pada indikator "frekuensi penggunaan media pembelajaran" yang menunjukkan hasil paling rendah dibandingkan variabel yang lainnya. Hal tersebut ditunjukkan dari hasil temuan bahwa walaupun dalam penelitian ini pengaruh dari persepsi memiliki persentase yang lebih tinggi dari variabel lainnya, akan tetapi kekurangannya yang begitu besar, disebakan karena pada tahun ajaran 2012/2013 SMK Negeri 1 Pamekasan masih menggunakan kurikulum KTSP sebagai acuan dalam proses belajar mengajar, akan tetapi pada tahun ajaran 2013/2014 kurikulum yang digunakan sebagai acuan berubah menjadi kurikulum 2013. Hal ini mengakibatkan proses belajar mengajar mata diklat kompetensi kejuruan APK, khususnya pada mata diklat sarana dan prasarana kurang bisa berlangsung secara optimal.

Hal-hal yang menyebabkannya antara lain menurut persepsi siswa adalah kurang tersedianya sumber-sumber belajar yang mendukung proses belajar mengajar, seperti tidak tersedianya buku paket, LKS sebagai latihan soal bagi siswa, modul sebagai pegangan guru dalam mengajar dan juga perubahan kurikulum tersebut mengakibatkan perubahan sejumlah mata pelajaran khususnya pada pembelajaran mata diklat kompetensi kejuruan, sehingga masih diperlukan proses pembiasan dan guru pun masih harus mencari berbagai sumber referensi karena belum tersedianya modul ajar.

Hal lainnya yang menyebabkan adalah media pembelajaran yang digunakan masih terbatas, sedangkan untuk pembelajaran mata diklat kompetensi kejuruan APK membutuhkan media pembelajaran yang dapat menunjang, akan tetapi pada kenyataannya media pembelajaran yang digunakan, hanya sebatas alat-alat perkantoran yang sederhana dan kurang melengkapi kebutuhan pembelajaran, selain itu masih kurangnya alat untuk menunjang praktek pada saat mata diklat 
berlangsung mengakibatkan siswa harus bergantian dalam penggunaan alat-alat perkantoran tersebut sehingga membuang waktu dalam proses pembelajarannya. Karena kurang sarana dan prasarana penunjang proses pembelajaran pada saat praktek mata diklat juga berlangsung seringkali siswa tidak mendapat giliran praktek pada saat jam pembelajaran, sehingga mereka hanya bisa mengamati tanpa ada pengalaman langsung dalam praktek penggunaan alat-alat perkantoran. Hal tersebut sangat disayangkan karena pada hakikatnya menurut Rusman (2012) dalam pembelajaran, media memegang peranan penting dalam mencapai tujuan belajar. Akibat dari kurangnya media pembelajaran yang tersedia, walaupun guru sudah berusaha secara maksimal untuk memberikan berbagai macam variasi model belajar, akan tetapi karena masih kurangnya sarana dan prasarana yang tersedia sehingga mengakibatkan terbatasnya model-model pembelajaran yang digunakan oleh guru.

Dari pembahasan diatas menunjukkan bahwa persepsi siswa terbukti dapat memberikan sumbangan positif untuk meningkatkan hasil belajar siswa kelas XI di SMK Negeri 1 Pamekasan khususnya pada mata diklat kompetensi kejuruan sarana dan prasarana. Hal tersebut sesuai dengan pendapat Novianty, dkk (2012) yang menyatakan bahwa persepsi siswa yang positif dapat meningkatkan hasil belajar dilihat dari keterlaksanaan modul efektif (media yang digunakan) dalam pembelajaran. Sehingga dapat disimpulkan bahwa dalam penelitian ini persepsi dapat terbukti menjadi faktor yang mempengaruhi hasil belajar siswa kelas XI di SMK Negeri 1 Pamekasan.

Berdasarkan hasil penelitian motivasi dan persepsi siswa tentang pembelajaran mata diklat kompetensi kejuruan APK terhadap hasil belajar siswa. yaitu hipotesis ketiga yang menyatakan bahwa diduga motivasi dan persepsi siswa tentang pembelajaran mata diklat kompetensi kejuruan APK secara bersama-sama berpengaruh terhadap hasil belajar siswa kelas XI APK di SMKN 1 Pamekasan teruji kebenarannya. Hal ini berarti motivasi dan persepsi secara simultan atau bersama-sama memiliki pengaruh signifikan pada hasil belajar siswa kelas XI APK. Maka, semakin baik motivasi dan persepsi yang dimiliki oleh siswa pada mata diklat sarana dan prasarana, semakin baik pula hasil belajar siswa kelas XI APK di SMK Negeri 1 Pamekasan yang mereka miliki

Hasil penelitian ini mendukung teori dan hasil penelitian sebelumnya yang dilakukan oleh Uno (2007) yang menerangkan bahwa motivasi belajar merupakan dorongan internal dan eksternal pada siswa-siswa yang sedang belajar untuk mengadakan perubahan tingkah laku, pada umumnya dengan mengacu pada beberapa indikator yang mendukung. Dan juga teori yang dikemukakan oleh Alfan (2013) yang menyatakan bahwa persepsi sendiri merupakan tanggapan atau penerimaan siswa yaitu tanggapan langsung dalam menafsirkan apa yang ditangkap oleh panca indera oleh siswa. Jadi sikap positif ataupun negative yang nantinya dilakukan oleh siswa terhadap pelajaran yang diajarkan tergantung dengan stimulus yang diberikan.

Hasil penelitian ini juga mendukung penelitian lainnya yang dilakukan oleh Aritonang (2008) yang menunjukkan bahwa ada hubungan yang signifikan antara variabel motivasi belajar siswa terhadap hasil belajar yang diperoleh, hal tersebut juga disebabkan oleh persepsi siswa yang memberikan tanggapan positif siswa pada modul yang dijadikan bahan penelitian. Responden mengungkapkan apabila mereka memiliki media dan sumber belajar yang cukup untuk menunjang proses 
belajar mengajar dalam mata diklat sarana dan prasarana maka dapat membangkitkan persepsi dan juga motivasi yang positif dalam diri mereka, sehingga hal tersebut akan mendukung mereka untuk mendapatkan hasil belajar belajar mata diklat sarana dan prasarana lebih optimal.

Motivasi belajar dan persepsi siswa berpengaruh signifikan pada hasil belajar mata diklat sarana dan prasarana siswa kelas XI APK di SMK Negeri 1 Pamekasan didukung oleh temuan bahwa variabel hasil belajar siswa dalam penelitian ini lebih dominan didukung oleh variabel motivasi belajar siswa yang baik hal ini dapat dimaklumi karena variabel motivasi belajar lebih besar dari variabel persepsi siswa dikarenakan kendala dalam ketersediaan media serta sumber belajar yang mumpuni mengingat kurikulum 2013 merupakan kurikulum yang baru digunakan pada saat ini, hal ini mengakibatkan masih belum maksimalnya kelengkapan media dan sumber-sumber belajar yang digunakan. Disamping tuntutan untuk terus melakukan proses belajar mengajar walaupun masih terdapat kekurangan sumber daya mengakibatkan guru dituntut untuk bekerja lebih ekstra dalam proses pembelajaran yang berlangsung walaupun hasil yang dicapai masih belum optimal.

Hasil temuan tersebut menunjukkan bahwa motivasi belajar dan persepsi siswa memberikan kontribusi yang positif bagi peningkatan hasil belajar siswa kelas XI APK di SMK Negeri 1 Pamekasan. Hal tersebut sesuai dengan penelitian-penelitian sebelumnya yang telah dijelaskan diatas. Sehingga dapat disimpulkan bahwa motivasi belajar dan persepsi siswa secara simultan berpengaruh signifikan pada hasil belajar mata diklat kompetensi kejuruan bidang sarana dan prasarana APK kelas XI di SMK Negeri 1 Pamekasan. Sedangkan diantara dua variabel tersebut, variabel yang paling dominan adalah variabel motivasi belajar siswa.

\section{SIMPULAN}

Simpulan dari pembahasan penelitian ini adalah sebagai berikut: Terdapat pengaruh motivasi belajar pada hasil belajar siswa kelas XI APK di SMKN Negeri 1 Pamekasan. Hal ini berarti motivasi belajar secara parsial berpengaruh signifikan dan positif pada hasil belajar mata diklat kompetensi kejuruan sarana dan prasarana APK. Hasil temuan pada penelitian ini lebih dominan didukung oleh indikator motivasi belajar yaitu hasrat keinginan berhasil dan dorongan kebutuhan dalam belajar. Hal ini dapat ditunjukkan dari temuan bahwa sebagian sebagian siswa di SMK Negeri 1 Pamekasan memiliki cita-cita yang ingin mereka wujudkan, hal ini mendorong keinginan mereka untuk memiliki hasil belajar yang tinggi. Sehingga para siswa berusaha keras untuk mendapatkan nilai yang baik disekolah dan memiliki dorongan kebutuhan dalam belajar untuk memperoleh pemahaman pelajaran pada mata diklat sarana dan prasarana di sekolah; Terdapat pengaruh persepsi siswa pada minat hasil belajar siswa kelas XI SMK Negeri 1 Pamekasan. Hal ini menunjukkan bahwa persepsi siswa secara parsial berpengaruh signifikan pada hasil belajar siswa. Semakin tinggi persepsi siswa terhadap mata pelajaran yang diajarkan maka semakin tinggi hasil belajar siswa SMK Negeri 1 Pamekasan. Hasil temuan pada penelitian ini lebih dominan didukung oleh indikator pemanfaatan media elektronik atau alat sebagai sumber belajar. Hal ini dapat ditunjukkan dari temuan bahwa sebagian siswa mendapatkan 
informasi tentang mata diklat sarana dan prasarana yang dipelajari lebih banyak dari intensitas penggunaan media internet sebagai sumber belajar mereka dibanding dengan penggunaan media ataupun sumber belajar lainnya; Terdapat pengaruh motivasi belajar dan persepsi siswa pada hasil belajar siswa kelas XI APK pada mata diklat sarana dan prasarana di SMK Negeri 1 Pamekasan. Hal ini menunjukkan bahwa motivasi belajar dan persepsi siswa secara simultan berpengaruh signifikan pada hasil belajar siswa. Semakin tinggi motivasi belajar dan persepsi siswa maka semakin tinggi hasil belajar siswa kelas XI APK di SMK Negeri 1 Pamekasan khususnya pada mata diklat kompetensi kejuruan (sarana dan prasarana). Hasil temuan pada penelitian ini menunjukkan bahwa diantara variabel-variabel tersebut yang lebih dominan berpengaruh pada hasil belajar siswa adalah variabel motivasi belajar.

\section{DAFTAR RUJUKAN}

Ahmadi, Abu, 2007. Psikologi Sosial. Jakarta: PT. Rineka Cipta

Alfan, Muhammad, 2013. Filsafat Kebudayaan. Bandung: Pustaka Setia

Arikunto, Suharsimi, 2008. Prosedur Penelitian Suatu Pendekatan Praktek. Jakarta: Penerbit Rineka Cipta.

Aritonang, Keke T., 2008. Minat dan Motivasi Dalam Meningkatkan Hasil Belajar Siswa. Jurnal Pendidikan Penabur. Vol. 7 No. 10 (Paper).

Dalyono, M., 2010. Psikologi Pendidikan. Jakarta: PT. Rineka Cipta

Dimyati \& Mudjiono, 2006. Belajar dan Pembelajaran. Jakarta: PT. Rineka Cipta.

Djamarah, \& Aswan Zain, 2002. Strategi Belajar Mengajar. Jakarta: Rineka Cipta Hamalik, Oemar, 2001. Proses Belajar Mengajar. Jakarta: Bumi Aksara

Hamdu, Ghullam, \& Agustina, Lisa, 2011. Pengaruh Motivasi Belajar Siswa Terhadap Prestasi Belajar IPA di Sekolah Dasar. Jurnal Penelitian Pendidikan Vol. 12 No. 1, April 2011 pp 81-86.

Hasibuan, Malayu, 2001. Organisasi dan Motivasi \& Dasar-Dasar Peningkatan Produktivitas. Jakarta: Bumi Aksara

Kiswoyowati, Amin, 2011. Pengaruh Motivasi Belajar dan Kegiatan Belajar Siswa Terhadap Kecakapan Hidup Siswa (Studi Tentang Pembelajaran Berorientasi Kecakapan Hidup di SMK Negeri 1 Losarang Kompetensi Keahlian Agribisnis Tanaman Pangan dan Hortikultura-Budidaya Cabe Hibrida). Edisi Khusus No. 1, Agustus 2011. ISSN 1412-565X (Paper) pp, 120-126

Lee, I-Chao, 2010. The Effect of Learning Motivation, Total Quality Theaching and Peer-Assested Learning On Study Achievement: Empyrical Analiysis From Vocational Universities Or Colleges' Students In Taiwan. Journal Of Human Resource. Vol. 6. Pp 56-73

Luis, jose., Seabra, Claudia., \& Filipe, Luis., 2007. Pedagogical Affect, Student Interest, and Learning Performance (Online). Journal Of Business Research 60 (2007) pp. 960-964.

Novianty, Iqma., Sulistina, Oktavia., \& Zakia, Neena, 2012. Efektivitas Penerapan Modul Materi Analisis Elektrokimia Berbasis Inkuiri Terbimbing Terhadap Hasil Belajar dan Persepsi Siswa Kelas XI Semester 1 Kompetensi Keahlian Kimia Analisis SMKN 7 Malang. 
Rahman, Afiv Roy, 2011. Pengaruh Motivasi, Lingkungan, dan Disiplin Prestasi Belajar Siswa Pada Jurusan Teknik AudioVideo SMK Negeri 3 Yogyakarta. Jurnal Penelitian Pendidikan. Pp 1-15

Rosilawati, Iyos, 2011. Pengaruh Persepsi Siswa Tentang Pembelajaran IPS dan Lokasi Terhadap Modal Sosial Siswa SMP di Kabupaten Subang. Jurnal Pendidikan (Online). ISSN: 1412-565X (Paper) Edisi Khusus No. 2, Agustus 2011.

Sarlito, WS., 2009. Psikologi Umum. Jakarta: Rajawali Press

Sarwar, Gul Shahzad, Carlos Zepra, Krystal Hackey, Marielle Simon, Christina Van Barneveld, 2012. Teaching Practice and Student Motivation That Influence Achievement on Large-Scale Asessment. International Journal of Education. Vol 4 No. 3 Pp 88-107

Slameto, 2010. Belajar dan Faktor-Faktor Yang Mempengaruhi. Jakarta: Rineka Cipta.

Stepp, Jonita, \& Greany, 2002. Student Perceptions On Language Learning In A Technological Environment: Implications For The New Millennium. Journal Language Learning \& Technology. ISSN: 1094-3501 (Paper) Vol. 6 No. 1 PP. 165-180, January 2002.

Sudjana, Nana, 2011. Penilaian Hasil Proses Belajar Mengajar. Bandung: PT Remaja Rosdakarya

Sugihartono, 2007. Psikologi Pendidikan. Yogyakarta: UNY Press

Sugiyono, 2011. Metode Penelitian Kuantitatif, kualitatif dan $R \& D$. Bandung: Alfabeta

Sulistina, Novianty, Iqma, Oktavia, \& Zakia, Neena, 2013. Efektivitas Penerapan Modul Materi Analisis Elektrokimia Berbasis Inkuiri Terbimbing Terhadap Hasil Belajar dan Persepsi Siswa Kelas XI Semester 1 Kompetensi Keahlian Kimia Analisis SMKN 7 Malang. Universitas Negeri Malang. Pp 1-7

Suyono \& Hariyanto, 2011. Belajar dan Pembelajaran (Teori dan Konsep Dasar). Bandung: PT. Remaja Rosdakarya

Syah, Muhibbin, 2005. Psikologi Belajar. Jakarta: Rajawali Press

Syukur, Fatah NC. \& Nor, Mohammad Ichwan (Eds), 2008. Teknologi Pendidikan. Semarang: Rasail Media Group

Tu'u, 2004. Peran Disiplin Pada Prestasi dan Perilaku Siswa. Jakarta: Grasindo

Uno, Hamzah B., 2007. Teori Motivasi Dan Pengukurannya. Jakarta: Bumi Aksara

Walgito, Bimo, 2003. Pengantar Psikologi Sosial. Yogyakarta: CV Andi Offset

Warsita, Bambang, 2008. Teknologi Pembelajaran Landasan \& Aplikasinya. Jakarta: PT. Rineka Cipta

Wayan, I Dwija, 2008. Hubungan Antara Konsep Diri, Motivasi Berprestasi dan Perhatian Orang Tua Dengan Hasil Siswa Kelas II Sekolah Menengah Atas Unggulan di Kota Amlapura. Jurnal Pendidikan dan Pengajaran Undhiksa. Vol. XXXXI No. 1, Januari 2008.

Wiyono, Bambang Budi, 2008. Metodologi Penelitian. Malang: Fakultas Ilmu Pendidikan Universitas Negeri Malang 